RESIDENT

\& FELLOW

SECTION

Section Editor

Mitchell S.V. Elkind,

MD, MS

F. Francesconi, MD

A.C. Francesconi do

Valle, $\mathrm{MD}, \mathrm{PhD}$

M.T.T. Silva, $\mathrm{MD}, \mathrm{PhD}$

R.L.B. Costa, MD, MSc

E. Carregal, MD

S. Talhari, MD, PhD

Address correspondence and reprint requests to Dr. Fabio Francesconi, Fundaçăo Centro de Controle de Oncologia do Amazonas, Rua Francisco Orellana, 215, Planalto Cep: 69040-010, Manaus, Amazonas, Brazil

fabiofrancesconi@globo.com

\title{
International Issues: Meningoencephalitis due to Paracoccidioides brasiliensis
}

Neurologic manifestations of paracoccidioidomycosis are uncommon. Generally, these are characterized by headache, seizures, or focal neurologic deficits due to a focal brain lesion. We describe a patient with subacute meningoencephalitis, CSF evidence of paracoccidioidomycosis, and striking abnormalities on brain CT scan. Combined fluconazole and sulfamethoxazole/trimethoprim was started with good response. The patient is asymptomatic after 10 years. Cerebral paracoccidioidomycosis should be included in the spectrum of possible causes of meningoencephalitis in a patient from an endemic region.

Paracoccidioidomycosis is endemic to Latin America. In Brazil, it is the most common deep mycosis and is prevalent mainly in rural areas, with an estimated annual incidence of 1 to 3 cases in every 100,000 inhabitants. ${ }^{1}$ In a few patients the infection results in overt disease that evolves into one of the two clinical forms: juvenile or adult type paracoccidioidomycosis. The CNS is affected in very few patients, mainly in those with the adult form. ${ }^{2-5}$ Generally, cerebral paracoccidioidomycosis is characterized by hypodense focal brain lesions with mass effect and contrast enhancement, resulting in focal neurologic deficits, headache, and seizures. Meningoencephalitis with psychiatric symptoms in the absence of meningeal signs or focal brain lesions has not been reported in cerebral paracoccidioidomycosis. We describe a case of meningoencephalitis and psychiatric manifestations secondary to Paracoccidioides brasiliensis infection in a patient with juvenile paracoccidioidomycosis without focal brain lesions on CT scan.

CASE REPORT A 21-year-old man presented with weight loss, dysphagia, oral lesions, and enlarged cervical lymph nodes evolving subacutely. $P$ brasiliensis was diagnosed by fungal culture following a lymph node biopsy. Diagnosis of juvenile paracoccidioidomycosis was made and sulfamethoxazole 800 $\mathrm{mg} /$ trimethoprim $160 \mathrm{mg}$ (SMZ/TMP) was started in accordance with Brazilian guidelines. ${ }^{6}$ However, there was recurrence of both oral lesions and lymph node enlargement due to failure to comply with the treatment after 16 months of follow-up. The same drugs were reintroduced but once again the patient did not take the medicine correctly. He was admitted 2 years later due to disseminated cutaneous lesions, daily persistent headache, visual hallucinations, delusional beliefs, disorganized thinking and lack of insight, psychomotor agitation, and mental confusion, all of which evolved within a few weeks. There were motor incoordination and brisk tendon reflexes diffusely, but neither nuchal rigidity nor other lateralizing deficits were observed. Mental evaluation showed temporal and spatial disorientation, memory deficits, dyscalculia, difficulty following commands, and visuospatial disorganization (Mini-Mental State Examination 7/30). Psychiatric assessment was compatible with acute delirium, with memory and attention impairment. A brain CT scan revealed diffuse cortical contrast enhancement without focal brain lesions or edema (figure). CSF was under normal pressure with 29 cells $/ \mathrm{mm}^{3}$ (80\% polymorphonuclear cells), $73 \mathrm{mg} / \mathrm{dL}$ glucose, and $42 \mathrm{mg} / \mathrm{dL}$ protein. Tests for syphilis, HSV-1/2, CMV, toxoplasmosis, HIV-1, and HTLV-1/2 were all negative. Direct examination and cultures for fungus, bacteria, and mycobacterium were also negative. Double-immunodiffusion for $P$ brasiliensis was positive with a titer of 1:64. Fluconazole plus SMZ/TMP was administered and maintained for 3 years. Complex partial seizures developed during the treatment and phenytoin was introduced. The patient is now asymptomatic and periodic CT scans of the brain show normal results after 10 years of follow-up.

DISCUSSION We describe an unusual neurologic presentation of the juvenile form of $P$ brasiliensis infection. Although rare, meningitis due to $P$ brasiliensis has been reported before. However, a focal brain lesion is normally seen in these patients. Indeed, al-

From Fundação Centro de Controle de Oncologia do Amazonas (F.F.), Amazonas; Instituto de Pesquisa Clínica Evandro Chagas (A.C.F.d.V., M.T.T.S., R.L.B.C., E.C.), FIOCRUZ, Rio de Janeiro; and Fundaçāo de Medicina Tropical do Amazonas (S.T.), Amazonas, Brazil.

Disclosure: The authors report no disclosures. 
Figure Atypical radiologic aspect of cerebral involvement of $P$ brasiliensis
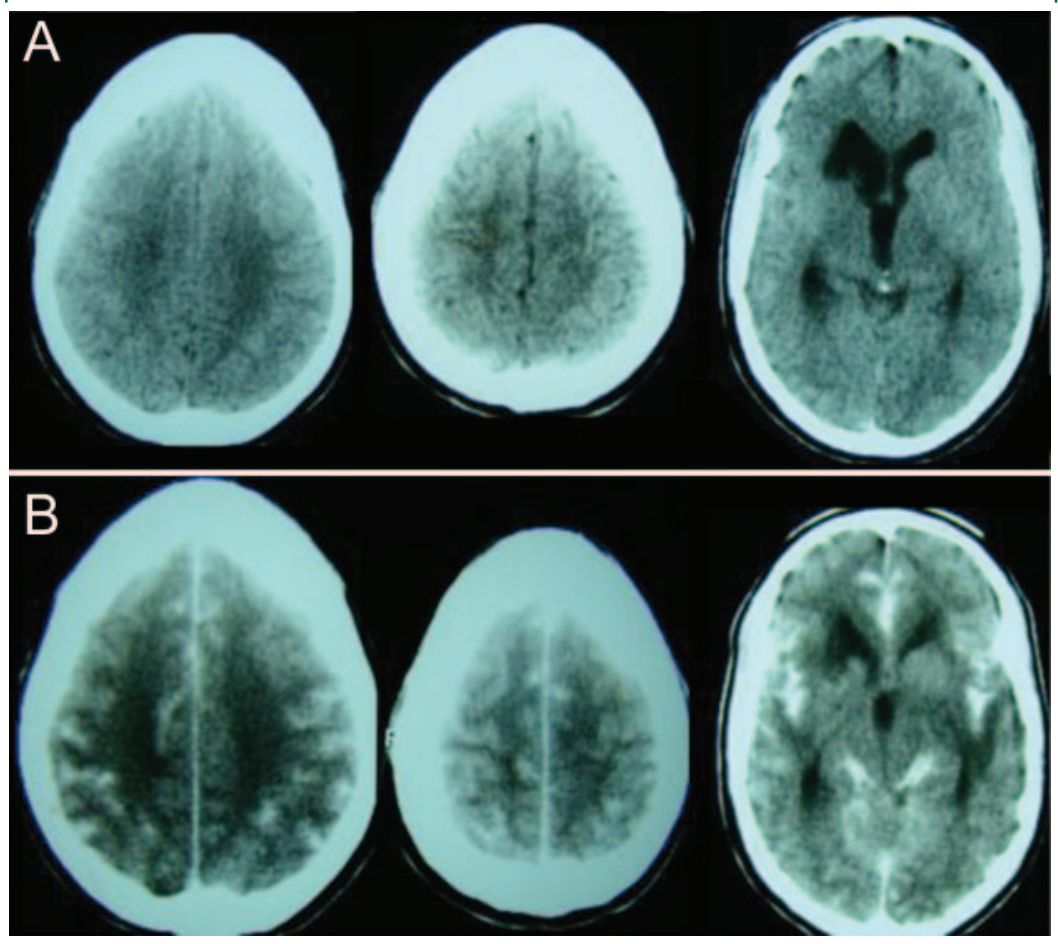

Brain CT scan shows (A) diffuse contrast enhancement in cortical-subcortical regions and (B) bilateral, dense enhancement in sylvian fissure.

most all cases of cerebral paracoccidioidomycosis, including those with meningitis and focal brain lesions, are diagnosed in patients with the chronic, adult form of paracoccidioidomycosis, but not in those with the juvenile or acute form of the disease. Another important difference in our case is the clinical presentation: normally, cerebral paracoccidioidomycosis is betrayed by focal neurologic deficits, seizures, new headache, or meningeal signs, the last one when meningitis is associated. This young man presented with acute delirium without meningeal signs or focal neurologic deficits.

Usually patients with this disorder are infected secondary to inhaling the conidia of the dimorphic fungus $P$ brasiliensis, present mainly in soil. Early infection results in a primary pulmonary infection. Only in a few patients does the primary infection progress to overt disease, which evolves into one of the two clinical forms: juvenile or adult type paracoccidioidomycosis. ${ }^{7}$ Juvenile or acute/subacute paracoccidioidomycosis is characterized by systemic lymphadenopathy, hepatosplenomegaly, and bone marrow dysfunction, usually affecting children, adolescents, and young adults. Adult or chronic paracoccidioidomycosis occurs years after primary infection. This chronic form affects men in the fourth decade of life and is characterized by progressive pulmonary and extrapulmonary manifestations, which include the CNS. ${ }^{1}$
A few small case series and collected case reports show that the CNS can be affected in $9.9 \%$ to $27.3 \%$ of patients. ${ }^{2-5}$ Generally, cerebral paracoccidioidomycosis results from hematogenous spread of a primary infectious focus and is mainly characterized by a hypodense lesion in the cerebral hemispheres with mass effect and contrast enhancement, sometimes resembling cerebral toxoplasmosis: this is called the pseudotumoral form of cerebral paracoccidioidomycosis. In some patients the cerebellum, brainstem, and spinal cord can also be affected. Other imaging abnormalities less frequently observed are calcified lesions and diffuse subarachnoid enhancement, the latter seen in less than $10 \%$ of cerebral paracoccidioidomycosis cases. ${ }^{8,9}$

The most frequent neurologic manifestations are seizures, hemiparesis, cerebellar signs, hydrocephalus, and headache. ${ }^{10}$ Meningeal symptoms and signs can be seen in a minority of patients, generally associated with diffuse subarachnoid enhancement and focal brain lesions. ${ }^{9} 10$ Our case report illustrates an atypical presentation of cerebral paracoccidioidomycosis.

Sometimes it is difficult to distinguish cerebral paracoccidioidomycosis from other diseases due to a lack of specific clinical or radiologic findings. The main differential diagnoses are bacterial abscesses, toxoplasmosis, and brain tumors. One very important aspect is that almost $90 \%$ of patients with cerebral paracoccidioidomycosis present evidence of paracoccidioidomycosis in other tissue, especially in the lungs. ${ }^{10}$ Clinical suspicion and epidemiologic data are of utmost importance to achieve the correct diagnosis. Cerebral paracoccidioidomycosis should be included in the spectrum of possible causes of meningoencephalitis in a patient from an endemic region and with evidence of a $P$ brasiliensis infection.

\section{REFERENCES}

1. Wanke B, Londero A. Epidemiology and paracoccidioidomycosis infection. In: Franco M, Lacaz C, RestrepoMoreno A, Del Negro G, eds. Paracoccidioidomycosis. Boca Raton: CRC Press; 1994:109-117.

2. Pla MP, Hartung C, Mendoza P, Stukanoff A, Moreno MJ. Neuroparacoccidioidomycosis: case reports and review. Mycopathologia 1994;127:139-144.

3. Fagundes-Pereyra WJ, Carvalho GT, de Miranda Goes A, das Chagas Lima e Silva F, de Sousa AA. Central nervous system paracoccidioidomycosis: analysis of 13 cases. Arq Neuropsiquiatr 2006;64:269-276.

4. Duarte R, Maia A, Duarte J, Furtado C. Cerebral paracoccidioidomycosis: case report and review of the literature. Res Pes Med 1997;31:37-41.

5. Pereira WC, Raphael A, Sallun J. Neurologic involvement in South American blastomycosis: pathologic study of 14 cases. Arq Neuropsiquiatr 1965;23:95-112. 
6. Shikanai-Yasuda MA, Telles Filho Fde Q, Mendes RP, Colombo AL, Moretti ML. Guidelines in paracoccidioidomycosis. Rev Soc Bras Med Trop 2006;39:297-310.

7. Almeida SM. Central nervous system paracoccidioidomycosis: an overview. Braz J Infect Dis 2005;9:126-133.

8. Elias J Jr Santos AC, Colli CGCBO, et al. Central nervous system paracoccidioidomycosis: diagnosis and treatment. Surg Neurol 2005;63(suppl 1):S13-21.
9. Gasparetto EL, Liu CB, Neto Carvalho A, Rogacheski E. Central nervous system paracoccidioidomycosis: imaging findings in 17 cases. J Comput Assisted Tomogr 2003;27: $12-17$.

10. Almeida SM, Queiroz-Telles F, Teive HA, Ribeiro CE, Werneck LC. Central nervous system paracoccidioidomycosis: clinical features and laboratorial findings. J Infect 2004;48:193-198. 


\section{Neurology}

International Issues: Meningoencephalitis due to Paracoccidioides brasiliensis

F. Francesconi, A. C. Francesconi do Valle, M.T.T. Silva, et al.

Neurology 2008;71;e65-e67

DOI 10.1212/01.wnl.0000335266.60637.c3

\section{This information is current as of November 17, 2008}

\section{Updated Information \&} Services

References

Citations

Subspecialty Collections

Permissions \& Licensing

Reprints including high resolution figures, can be found at: http://n.neurology.org/content/71/21/e65.full

This article cites 8 articles, 0 of which you can access for free at: http://n.neurology.org/content/71/21/e65.full\#ref-list-1

This article has been cited by 2 HighWire-hosted articles: http://n.neurology.org/content/71/21/e65.full\#\#otherarticles

This article, along with others on similar topics, appears in the following collection(s):

Fungal infections

http://n.neurology.org/cgi/collection/fungal_infections

Information about reproducing this article in parts (figures,tables) or in its entirety can be found online at:

http://www.neurology.org/about/about_the_journal\#permissions

Information about ordering reprints can be found online:

http://n.neurology.org/subscribers/advertise

Neurology ${ }^{\circledR}$ is the official journal of the American Academy of Neurology. Published continuously since 1951, it is now a weekly with 48 issues per year. Copyright . All rights reserved. Print ISSN: 0028-3878. Online ISSN: 1526-632X.

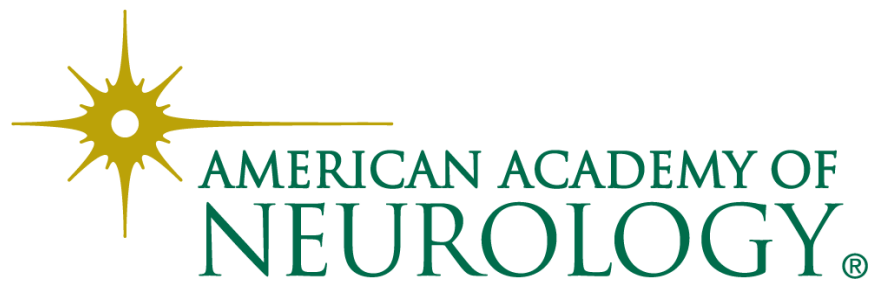

